\title{
7 Federalism in Times of Increased Integration: The Participation of Cantons in Swiss Trade Policy
}

\author{
ANDREAS R. ZIEGLER
}

Switzerland's federalism is generally known as being a prime example of power-sharing between a federal government and states. It is still based on the ideas enshrined in the first constitution of the consolidated nation state of 1848 . What is less known is how cantonal involvement in trade policymaking has changed over the last twenty-five years. As elsewhere, due to increased globalization and economic integration - in particular, at the European level - the mechanisms to involve the cantons have evolved considerably, leading to the creation of new institutions and procedures. While some of them are formalized, others are more informal and still in the making. At the same time, the capacity of the relatively small sub-federal entities in Switzerland heavily limits their possibilities to influence directly the international relations of Switzerland in a systematic and comprehensive way. The federal government still enjoys exclusive competence in this field (like in all its foreign policy), yet it must now take into account the particular interests of the cantons and consult them in those areas. The final ratification of trade agreements does not normally involve the cantons directly but only through their representation in Parliament.

Using the especially important agreements between Switzerland and the European Union as an example, this chapter demonstrates the changing role of the cantons in trade policy that has taken place since the early 1990s. Overall, it concludes that increased sub-federal involvement has resulted in better acceptance of the negotiation results by the cantons (and thereby the population in general), but at the price of slower and more complicated communication procedures, which affects the flexibility of the federal government. One can probably say that in Switzerland the strong engagement of the cantons is primarily a consequence of two factors: strong institutional resources and the changing nature of trade policy. Societal mobilization also plays a 
certain role, but the role of societal actors and political parties in trade policy is mostly visible at the federal level because the country is relatively small, and many of the cantons are very small. For parties, nongovernmental organizations (NGOs), and lobbies it is more efficient to work at the federal level, mostly through their offices in the capital.

\section{Situating the Swiss Case}

Like many federal states, Switzerland was created as a modern state in the nineteenth century from a group of formerly independent territories. Some of these territories, traditionally known as cantons, had concluded military alliances as early as the thirteenth century; ${ }^{1}$ others were created as a result of wars and territorial agreements between European powers only in the nineteenth century. During the Napoleonic occupation in the early nineteenth century they had for a short period been joined in a centrally organized state (the so-called Helvetic Republic) following the French tradition, but they only became a modern unified federal state in 1848 when (after a short civil war) the Constitution of the Swiss Confederation was adopted (Federal Constitution 1848). This constitution underwent a major reform in 1874 (Federal Constitution 1874) and was updated (though not fundamentally altered) in 1999 (Federal Constitution 1999). ${ }^{2}$ The constitution of 18 April 1999 contains the basic rules on the participation of the Swiss cantons in foreign policy, including trade policy.

Before becoming part of the new federal state, the cantons had, in principle, their own foreign policy, including trade policy. In order to strengthen the international position of the cantons, the agreements between them most often involved questions regarding their political and military relations with foreign powers. Important treaties were concluded from the fifteenth century onwards between most or all of the cantons and France, the Habsburg Empire, Spain, Milan, Venice, Savoy, the Holy See, the Netherlands, and England (see Behr 2014). ${ }^{3}$ The Swiss cantons heavily depended on the income from trade with these powers (in particular, exports of livestock and milk products) and from the sale of mercenaries, an ancient type of modern human trafficking or trade in services. Many treaties were concluded to obtain trade preferences and a guaranteed market access. The import of salt was of fundamental importance and often an important element of these treaties. In the eighteenth century, exports of textiles became important. Already in 1815 , the power to conclude military alliances and trade agreements was, in principle, transferred to the central organ of the cantons for joint 
decision making, but the remaining powers of the cantons to conclude economic agreements were still relatively important (see Kreis 2012).

The constitution of the newly created federal state of 1848 contained the basic model of the cantons' participation in foreign affairs (including trade policy), which is still in force today. In principle, the constitution introduced the full competence of the federal state to declare war and conclude treaties, even in those areas where the cantons were competent domestically. The text mentioned explicitly that the federal competence included the conclusion of customs and trade agreements with foreign states (Federal Constitution 1848, article 8). At the same time, the cantons kept the right to conclude their own treaties with foreign states in the areas of the state economy, cross-border transport, and police cooperation, as long as these treaties did not infringe the rights of the federal level or other cantons (article 9). In these areas, direct negotiations and contacts between the cantons and foreign entities were allowed; in all other questions, they had to be arranged through the federal government (article 10). The constitution of 1874 contained exactly the same provisions.

Although Switzerland is often studied, and sometimes admired, as a well-functioning federal state, one should not forget the specific geopolitical and geographic conditions under which it has evolved. Today the whole country has approximately 8.4 million inhabitants. Of these, approximately two million are foreigners who have no voting rights at the federal level (and normally neither at the sub-federal level nor at the local level). The country is made up of twenty-six cantons. These differ enormously in actual size and even more so in the size of their population and economic structure. Zurich alone has approximately 1.4 million inhabitants and thus is home to one-sixth of the total population, but there are at least eight cantons with less than 100,000 inhabitants (and are therefore smaller than an average town in most countries). Another five cantons have less than 200,000 inhabitants. Among the bigger cantons (after Zurich), it takes only four more cantons - Berne (980,000 inhabitants), Vaud (718,000 inhabitants), Aargau (613,000 inhabitants), and St Gallen (479,000 inhabitants) - to reach more than half of the population of the country. An additional issue is the fact that the country has four official languages, and therefore the balance between the Germanic part of the country (approximately two-thirds of the population) and the Latin part (one-third of the population, comprising the French, Italian, and Romansch languages) is an important factor in daily politics (see Wouters, Van Kerckhoven, and Vidal 2016). ${ }^{4}$ 


\section{Institutional Foundations of Cantonal Participation}

The constitution of 1999 did not totally change the principles governing the involvement of the cantons in foreign policy matters but essentially led to a more detailed description of the rights and duties of the federal level and the cantons (for an account under the old constitution see Schmitt 1994, 362). ${ }^{5}$ The foreign relations power is now described at the very beginning of the second chapter of the constitution (1999) relating to the powers of the federal level (articles 54-56, sec. 1; articles 57-61, sec. 2). ${ }^{6}$ In addition, chapter 3 of the constitution speaks about how the federal government and Parliament share their powers when dealing with foreign relations (articles 184, 186). ${ }^{7}$ As we will see, the cantons normally deal directly with the federal government, but they can also use certain mechanisms to influence the federal parliament.

\section{Competencies}

The most important cantonal powers currently lie in the areas of education, health care, police, construction, and local infrastructure, including public transport and energy and water supply. ${ }^{8}$ In addition, the cantons often have the task of implementing federal policies - that is, in the area of labour conditions, immigration, or some aspects of environmental policy (for an example related to environmental policy see Casado-Asensio and Steurer 2016). As a consequence, these are the areas in which more examples of friction between Switzerland's foreign affairs and their activities and interests exist.

An important addendum to the constitution of 1999 is a provision that states explicitly for the first time that the federal level in its relations with foreign states "shall respect the powers of the cantons and protect their interests" (article 54, paragraph 3). Furthermore, the cantons are given specific procedural rights to participate in the making of foreign-policy decisions by the federal level (article 55).

Besides these new elements in the constitution of 1999 and some added details regarding existing principles, in the very same year a new federal law was adopted to fill these provisions with meaning, the Federal Law on the Participation of the Cantons in the Foreign Policy of the Swiss Confederation, on 22 December (BGMK 1999). ${ }^{9}$ This law is mostly concerned with increased participation in the negotiations of international agreements, and the ratification of these agreements is governed by the ratification provisions in the constitution (which shall be treated in the next section). 


\section{Intergovernmental Relations}

The BGMK was Switzerland's first attempt to find solutions to the increased importance of international developments and, in particular, binding international agreements at the local level. This process is often associated with the phenomenon of globalization, though one can show that developments of a similar nature had already taken place in the late nineteenth century. Nevertheless, as in many other countries, the developments since the Second World War (especially in the 1980s and 1990s) have led to a widespread and intense perception that local autonomy and existing powers are more and more affected by increased cooperation at the global and European level. The resulting rules and principles do limit the scope for national and sub-federal decision making (see Füglister and Wasserfallen 2014). As international negotiations are traditionally the responsibility of the federal government, the federal parliament, citizens (direct democracy), and the cantons were looking for ways to influence this process, be it before, during, or after the negotiation of binding international rules or even of legally non-binding rules that could still de facto limit their impact (see Cina 2016).${ }^{10}$ Consider the following:

- Article 1 of the BGMK takes up the general principle that the cantons must be allowed to participate in all processes (i.e., decision making) led by the federal government internationally whenever the processes affect areas in which the cantons are competent at the domestic level or, generally, where their essential interests are concerned. According to the text of the constitution, the essential interests of the cantons are always concerned when such international decisions lead to important implementation tasks at the cantonal level (paragraph 2). Although the law states that this participation in the decision making should not hamper the effectiveness of Swiss foreign policy (paragraph 3), there are no clear indications on how this should be prevented or when this would be the case.

- Article 2 states the objectives of cantonal participation in the negotiations. The cantons will have an opportunity to defend their interests regarding the outcome of the negotiations as such and the necessary implementation that they will have to ensure. Where possible, they should be given the chance to prevent an erosion of their own powers. In addition, it is hoped that this participation gives domestic legitimacy to the outcome of the negotiations by the federal government. 
- In general, cantons and the federal government are to exchange as much information as possible. In particular, the federal government will inform the cantons early and comprehensively on the issues at stake in upcoming negotiations whenever they ask for it (article 3). Before negotiations are undertaken, the federal government must give the cantons an opportunity to express their views in a consultation process. This special consultation process comes in addition to the existing consultation of various stakeholders that is traditionally undertaken for major negotiations (just as for special legislative projects). Whenever the position of the cantons is not respected, though their domestic powers are affected, the federal government needs to provide justification (article 4).

- The federal government can include representatives of the cantons in the preparation of a specific negotiation mandate as well as in the negotiating teams themselves. Whenever their powers are affected, they normally have a right to such representation. The cantons must decide among themselves how they want to nominate the respective representative(s), although the official appointment is the prerogative of the federal government (article 5).

- All information exchanged between the cantons and the federal government is to be treated as confidential (article 6).

- In the final operative provision of the law (article 7), the generally accepted (but so far unwritten) principle of Swiss constitutional law is codified for the first time, that the cantons have a legal obligation to implement international commitments entered into by the federal government.

The existence of the specific BGMK does not mean that other policy instruments that had already existed before the coming into force of this new law cannot be used by the cantons to defend their strategic trade interests. One such instrument is the so-called Cantonal Initiative (Standesinitiative) (Federal Constitution 1999, article 160, paragraph 1). ${ }^{11}$ Under this rule a policy proposal must be treated by the federal parliament and can potentially lead to a binding decision for the federal government (for a description of the role of the federal parliament, see Granat 2017). ${ }^{12}$ Although this was traditionally not often the case, these requests can concern the foreign trade policy of the country. It seems that the use of such initiatives has increased in recent years. A good example is a recent cantonal initiative by the canton of Vaud. In April 2016 this canton's parliament adopted a cantonal initiative to request that, in the ongoing negotiations between Switzerland and Malaysia, market access liberalization for palm oil not be included. Although 
several NGOs and lobbies had already submitted similar proposals, mostly for ecological reasons that see the production methods of palm oil in Malaysia as unsustainable, the request by this canton was mostly motivated by economic, that is, protectionist reasons. Vaud has a relatively important agricultural sector and produces a fair amount of colza (rapeseed) oil (BauernZeitung 2016). In July 2016 a parallel initiative was discussed by the big chamber of the canton of Thurgau, another canton with an important agricultural sector. The federal government had always rejected a total ban or exclusion from the negotiations because this is an important sector for Malaysia, and the federal government would prefer to find rules regarding the production methods (to ascertain sustainability) and/or quotas to limit the negative effects (Neue Zürcher Zeitung 2016). This is not the first time that the importation of palm oil has been discussed in the federal parliament following a cantonal initiative. In 2012 a general ban, which was not limited to a specific negotiation of a free trade agreement with a known partner, for the import of palm oil was requested by the canton of Fribourg. Ultimately, however, this initiative was rejected by Parliament in 2013. ${ }^{13}$

Another example of a cantonal initiative that concerns directly international trade negotiations is the one submitted by the canton of Geneva, which hosts the WTO among other international organizations, in early 2015. It requested the federal government to disclose immediately the available information on the negotiations for a trade-in-services agreement and to promise not to make any commitments leading to privatizations or a reduction of public services. In addition, this cantonal initiative wanted the federal parliament to endorse a request to subject the result of the negotiations to a referendum in which both the majority of the voting citizens and a majority of all cantons would have to vote positively. Equally, this initiative was rejected by Parliament in 2016. In this case, it became apparent that the parliament of the canton of Geneva was very concerned about the legitimacy of services negotiations in general and questioned not only the way this agreement was being negotiated but also the potential outcome. The idea that public services should be of a high level and that there be less room for the private sector in the areas of health care or education is heavily influenced by neighbouring France and, thus, is an important political issue in this region of the country.

So far, the cantonal initiatives in the area of foreign trade have seldom been accepted by the federal parliament, but an increase in their use seems apparent. Generally, the federal parliament defends a position that allows the federal government to participate actively in international and bilateral trade negotiations. This does not mean 
that protectionist policies do not influence the Swiss position in negotiations, but the federal parliament has so far been confident that the federal government itself knows the politically acceptable limits when it comes to liberalization of access to the Swiss market, particularly in the areas of agriculture, public services, and migration. Yet, the possibility that certain cantons will try to limit the negotiating freedom of the federal government in advance or during negotiations, through cantonal initiatives submitted to the federal parliament, should not be neglected in the future.

As in other federal states (for example, Belgium), the ratification process of certain international agreements is subject to approval by cantons in addition to the more common approval by the two chambers of the federal parliament. This procedure was codified in more detail even before the entry of the new constitution of 1999 and before the rules on participation in ongoing negotiations just outlined. Although the constitutions of 1848 and 1874 foresaw the approval of certain treaties by the federal parliament, an amendment in 1921 was voted to subject certain important treaties to additional approval by the citizens in a referendum (direct democracy) (Popular Initiative 1921, article 89, paragraph 4). ${ }^{14}$

Much later, in 1977, this provision was extended to include the approval by a majority of the cantons in certain rare cases. Interestingly, when the first constitution was discussed in 1848, at least one canton requested that all treaties should be approved by a majority of the cantons - a proposal that was rejected..$^{15}$ Similar proposals by Members of Parliament in the nineteenth century did not receive much support. For the first time, in 1972, when Switzerland concluded its first bilateral trade agreement with the European Union (at that time the European Economic Community), the federal government decided to submit the agreement to a referendum, which, for the agreement to be accepted, required a majority of the voting citizens and a majority of the population of each canton to vote in favour of it. This was controversial because it was not explicitly foreseen in the constitution. The federal government argued that the ratification of such an important agreement should be treated like a change of the constitution, which requires the application of this procedure. The idea that agreements of the same importance to the country as a change in the constitution should be accepted by a majority of the cantons was formally introduced by an amendment to the constitution in 1977. Since then, all treaties leading to membership in an international organization in the area of collective defence or of a supranational character have been subjected to approval by both the majority of all voting citizens and a majority of the cantons (Federal Constitution 1874, amend. 1977, article 89, paragraph 5). 
Additionally, for a wider group of treaties eight cantons can request that the approval of the treaty be subject to a referendum in which a majority of those who vote have to support it. It is extremely rare that eight cantons decide together to use this prerogative, and it has so far never happened with regard to foreign policy issues (for news coverage see Neue Zürcher Zeitung 2013). ${ }^{16}$ This solution in the constitution of 1999 is still in force today (article 140, paragraph 1b).

Interestingly, as had been done in 1972 with regard to the first free trade agreement concluded with the European Union, the ratification of the comprehensive trade agreement creating a European Economic Area, between the European Union and members of the European Free Trade Association (EFTA), in 1992 was subjected to approval by both a majority of the voting citizens and a majority of the cantons. This was done despite the fact that legally the agreement did not require such a double majority under the constitution, because it neither led to membership in an international organization in the area of collective defence nor was it of a supranational character. In this case, the federal government felt that the economic and political consequences of the agreement were so important that they justified such a procedure. The debate on whether this constituted a violation of the constitution was intense but ultimately without consequence. As a matter of fact, this agreement was very comprehensive and basically would have led to an integration into the internal market of the European Union without proper membership. ${ }^{17}$

In 2012 a proposal for another amendment of the constitution was voted that would have extended the number of cases in which a majority of the cantons would have to vote in favour of the ratification of an international agreement. More than 75 per cent of the voting citizens and all the cantons rejected this proposal. Nevertheless, discussions continue regarding which international treaties should be subject to joint approval by the majority of the voting citizens and the majority of the cantons. ${ }^{18}$

While it is thus rare that a majority of voters in a majority of cantons have to approve a specific treaty by way of a referendum, the cantons can always try to influence the federal parliament before it has to ratify the treaties. The situation in which Parliament has to approve international treaties is much more common, in particular when it comes to trade agreements that are normally not subject to a referendum (though it is more common today for NGOs to request it). It is not always easy to isolate, from other interest groups, the influence of specific cantons on the federal parliament when it approves international treaties, but there are rare instances in which it was generally agreed that the view 
of one or several cantons influenced the outcome of a vote (which was negative, an unusual result).

The most striking example in recent years was probably the negative vote by the federal parliament regarding an agreement with Germany on air traffic originating at Zurich airport. This airport (like all Swiss airports) is relatively close to the border and thus leads to regular complaints by the German border regions that are most affected by the noise. It is by far Switzerland's biggest airport and since the 1990s has increasingly been used as a hub, with many passengers in transit. One can thus consider this a case of trade in services because Swiss and foreign airlines create jobs and tax income in the Zurich area by servicing international (transiting) passengers who could otherwise use another airport in Europe. In 2001 a new agreement was negotiated between the German and Swiss governments that was considered relatively restrictive by the German Land of Baden-Württemberg on behalf of its local population. Consequently, discussion in the Swiss federal parliament was very heated. The bigger chamber of Parliament rejected the treaty on 19 June 2002, and the smaller chamber did so on 18 March 2003. ${ }^{19}$ It was generally held that the negative comments of the canton of Zurich had had a decisive influence on the Members of Parliament. Ten years later a new agreement was negotiated by the Swiss and German governments. A member of the Zurich cantonal administration (from the unit responsible for foreign affairs and, in particular, European affairs) had been included in the Swiss delegation during these negotiations. The outcome was even less favourable from a Swiss perspective, but this time the canton of Zurich supported the ratification of the treaty, ${ }^{20}$ which led to a positive vote in the Swiss parliament; the German side never submitted the treaty to Parliament.

As elsewhere in Europe, the debate on the effects of globalization on society intensified in the 1980s and early 1990s; some would even say that it started in the 1970s. For the cantons this discussion mostly focused on the need to safeguard their interests in the negotiations, in the conclusion of international treaties, and in the formulation of common policies in international organizations, mostly at the regional European level but also at the global level. This need was particularly important due to the relative openness of the Swiss economy and the strong need to have access to international markets in view of the small size of the economy and the absence of natural resources. Two important milestones in this debate were the negotiation of a European Economic Area with the European Union (1989-92) (see Schweizer 1992, 59 ) and the conclusion of the Uruguay Round leading to the creation of the World Trade Organization (WTO) in 1995 (see Wasescha 1996). 
These discussions and developments triggered the creation of a body in which the cantons discuss and coordinate their interests regarding Switzerland's foreign policy: the so-called Conference of the Cantonal Governments (Konferenz der Kantonsregierungen, KdK).

It became apparent, and is still vividly discussed today, that the request for better inclusion in foreign policymaking also required the cantons to increase both their ability to participate actively and their expertise in the area. This was particularly felt with regard to European integration because Switzerland over time was increasingly surrounded by members of the European Union to and from which most products, migration, and capital flow. The KdK was seen as the first institutional improvement that could help the cantons to strengthen their position. It was established on 8 October 1993 as a permanent body under a specific treaty between all twenty-six cantonal governments. ${ }^{21}$ The KdK has a secretariat based in Berne, Switzerland's capital. Regular meetings of a plenary assembly are foreseen, but in practice many specific working groups do most of the substantive work. These groups deal with areas of cooperation between Switzerland and the European Union that are particularly important for the cantons because they touch upon their domestic powers (such as migration, security, and recognition of diplomas). ${ }^{22}$

Many of the working groups deal with topics that today are included in modern comprehensive trade agreements, like the free movement of workers and professionals who provide services, or of specific services sectors (education, air transport), but no working group is devoted to trade in general that is not related to the European Union. Owing to the paramount importance of Europe for Swiss foreign trade policy, all working groups focus on the European Union. The KdK acknowledges, however, that at the global level Switzerland's foreign economic policy (in particular when it involves the liberalization of certain services, migration, and investment flows, for example) affects also the cantons and their interests. As an example, the granting of market access to foreign service suppliers can lead to specific quotas for workers that need to be controlled at the cantonal level, as the federal authorities have no staff and administrative bodies to do this. The same is true when it comes to the recognition of diplomas or the issuance of work permits. The representation of the KdK's interests at the federal level is undertaken by the secretariat of the $\mathrm{KdK}$. The members of the secretariat can represent the $\mathrm{KdK}$ in working groups or other bodies established by the federal government, as well as in delegations that participate in international negotiations, as foreseen in the Law on the Participation of the Cantons in the Foreign Policy of the Swiss Confederation. In addition 
to European integration, the $\mathrm{KdK}$ is particularly interested in the negotiations of the WTO and bilateral free trade agreements. ${ }^{23}$ This is due to the fact that, so far, the access to domestic services markets for foreign companies and their detached workers has been discussed mostly in these settings.

One additional area of foreign trade that interests the cantons particularly is public procurement. It is also increasingly common to subject the purchase of goods and services by sub-federal entities to the disciplines negotiated in the framework of the Government Procurement Agreement of the WTO and respective chapters in free trade agreements. Public procurement issues are dealt with by a separate body created by the governments of the cantons through a convention in 2009, the Conference of Directors for Planning, Construction, and the Environment (Bau-, Planungs- und Umweltdirektoren-Konferenz, BPUK). ${ }^{24}$ Like the KdK, it is a public body, composed of the members of each cantonal government responsible for planning, construction, and the environment. In addition, this body has a member from the Principality of Liechtenstein and the Association of Towns and the Association of Communes. It is not legally related to the $\mathrm{KdK}$, as are several other such bodies created by the cantons for coordination in specific areas. Nonetheless, all these bodies use the infrastructure of the $\mathrm{KdK}$ and meet regularly in its offices in Berne. The BPUK, which deals not only with international negotiations, is in charge of public procurement because construction projects are particularly important when it comes to public procurement at the local level.

The secretariat of the $\mathrm{KdK}$ is managed by an independent institution, the Ch Foundation for Confederal Cooperation, which the cantons created in $1967 .{ }^{25}$ Within this body one staff member (of a total of three working at the headquarters) is in charge of foreign affairs. Currently this is Roland Mayer, who has held the position for many years and thereby has become part of the foreign policy landscape in this small country. He is in charge of an additional three persons who have their workplace directly within federal government offices. Two members of staff are delegated to the federal Ministry of Foreign Affairs unit in charge of negotiations with the European Union, the Directorate for European Affairs. A third person is delegated to the federal Ministry of Foreign Affairs, not in Berne but in the Swiss Mission to the European Union in Brussels. ${ }^{26}$

At the local level, it must be remembered that obviously the bigger cantons simply have more resources than the others to deal with foreign affairs. The smallest canton of Appenzell Innerhoden with its sixteen thousand inhabitants acts differently than the biggest, the canton 
of Zurich, with its 1.4 million inhabitants. The latter, like many other large cantons, has created within its administration a special unit to deal with external matters, although this often includes not only relations with other states or international organizations but also issues pertaining to other cantons or neighbouring regions. ${ }^{27}$ Some of these bodies are quite active when it comes to, for instance, the promotion of their economic interests abroad. As a recent example, we can mention the organization of a networking meeting between Chinese investors and the local authorities in Zurich. ${ }^{28}$ Even the biggest of these sub-national actors are too small, however, and their administrative capacities are too limited to shape the foreign relations of the country as a whole in a systematic and direct matter. Their influence is sometimes even further reduced by the absence of a common standpoint among the cantons (or absence of even totally opposite views). As the number of cantons is relatively high, the likelihood of finding a common denominator is small, and their economic situations are so diverse that they hardly ever fight together for a specific point. In this sense, sectoral lobbies (such as farmers, financial services providers, and the pharmaceutical industry) are more likely to succeed. They may be supported by those cantons to which their specific economic activity is particularly important.

A good recent example in this respect is the response by Switzerland to pressure within the Organisation for Economic Co-operation and Development (OECD) and from the European Union to revise its domestic corporate tax system. The issue had led to tensions between Switzerland and its neighbours since the early 2000s, escalating after the financial crisis in 2008. As corporate tax is, to a large extent, within the competence of the cantons, any revision of the corporate tax system would immediately affect their regulatory authority and have a direct impact on the income available to them. The negotiations in the OECD and with the European Union led to the threat of blacklisting Switzerland if some favourable tax treatments available to multinational companies (e.g., tax breaks on overseas earnings) were not ended. This required a total overhaul of the corporate tax system for all companies, leading to a discussion of the extent to which this would affect the attractiveness of certain cantons to multinational companies. Not all cantons were affected by this question in the same way, as some regions of the country are more attractive to multinational companies than others. The federal government involved the cantons heavily in a reform proposal that ultimately had to be submitted to a popular vote in a referendum. In this case, all cantons were directly affected by the international pressure and thus had an interest in finding a solution. They issued a common statement on 13 
January 2017, inviting voters to adopt the proposal (in order to avoid being blacklisted at the international level). ${ }^{29}$

\section{The Second Chamber}

Since 1848 the Swiss constitutional system has been characterized by a two-chamber system, which some say was due to the liberal elite's admiration of the system introduced in the United States. One chamber, the Nationalrat (National Council), is made up of representatives of the people (with larger cantons having more representatives than smaller ones), and the other chamber, the Ständerat (Council of States), represents the cantons; that is, each canton has two representatives (the Council of States)..$^{30}$ The cantonal representatives in the Council of States do not have to take instructions from their respective cantonal governments, but they are usually considered to be taking into account the interests of their local voters and thereby, to a large extent, the interests of their canton. In some cantons liaison with the cantonal representatives in the federal parliament (both chambers) is officially undertaken by the special units, with the administration dealing with foreign affairs. One would think that the members of the Council of States would see their role as mostly defending the interests of their cantons. This, however, is usually not the case. In both chambers one can observe that the votes of the representatives are normally more related to the party affiliation of the cantonal delegates than to the cantons they represent. Some observers even think that this may be an additional reason to create the KdK as another, informal "state organ" (not foreseen in the constitution) (see Vatter 2016, 342). This seems also true in the area of trade, where delegates in both chambers may defend or take up specific, important issues that affect their canton, but here again the ideological view of a particular delegate normally prevails.

\section{Functioning of the Current System}

Despite the fact that the participation of the Swiss cantons was codified in more detail in 1999 than it had been previously, and the cantons have since created institutions to effectively use their rights, the system is still considered insufficient by many observers. The cantons have repeatedly stated that they are not happy with the current system; they see the need for a more in-depth reform of Swiss federalism and of the cooperation between themselves and the federal government when it comes to foreign trade policy. Again, this is mostly triggered by the very complex and comprehensive relations with the European Union. More 
recently, they made public statements on 24 June 2011 and 13 December 2013 that they would only support the federal government in its future negotiations with the European Union if domestic reforms regarding the federal structure and democratic participation were launched. ${ }^{31}$ The cantons want to achieve an even more far-reaching participation in the foreign policy of Switzerland, and they have made several concrete proposals for reform:

1. The cantons want to be informed early - not only when their powers are concerned but also, generally, when their interests (even potentially in the future) are concerned.

2. The cantons want to have at least three months before presenting their own position. Only this would allow them to consult stakeholders meaningfully. A shorter period seems to them to be unrealistic and threatens their right to participate actively in the decision-making process.

3. When it comes to questions regarding European integration, often on the subject of trade, the cantons want to enhance the weight of their own position. The government should only be allowed to defend another position if preponderant foreign-policy interests can be invoked.

4. The existing informal dialogue between the federal government and the cantons is considered to be insufficient. The cantons would like to see the creation of a standing body for the sole purpose of discussing foreign affairs with the federal government and the cantons. This body should be used for all areas of foreign policymaking, though the complexity and abundance of decisions related to the European Union are again at the origin of this proposal.

5. So far, there is a foreign-policy dialogue between the federal government and the cantons. The cantons, however, see that the federal government is also influenced by Parliament, and thus they would like to participate in the meetings and discussions of the specialized parliamentary committees, through either written submission or active participation in the meetings. Already at this stage it is not uncommon for the parliamentary committees to invite representatives of the cantons to hearings.

On several occasions the representatives of the cantons have voiced their concern regarding the current system and the importance of adopting the suggested reforms. Most recently, the president of the KdK has even threatened to sue the federal government before the Supreme Federal Court, exercising a type of constitutional jurisdiction 
in this context. The $\mathrm{KdK}$ is of the opinion that the federal system as a whole is in need of reform to take into account the increasing complexity of decision making at the federal level, which often affects, directly or indirectly, the cantons. Foreign affairs and trade play an important role in this, but the phenomenon is more widespread.

\section{Conclusions}

The discussion on how the relationship (and the institutional balance) between the cantons and the federal level in Switzerland is affected by increasingly intense and far-reaching foreign affairs has been significant in the country over the last thirty years. The most important part of Swiss foreign policy has always been trade and economic integration. This has been exacerbated by the creation of the European Union, where purely economic and other aspects of cooperation and integration often converge. Switzerland is one of the few remaining European states that is not a member of the Union, and as a rather small, export-oriented state, it depends on its European markets. As a result, its foreign policy is heavily dominated by its bilateral relations with the European Union. The perceived change in the federal structure in Switzerland is, therefore, often discussed because of European integration.

But this does not mean that other areas of trade with partner countries that are farther afield or within global organizations like the WTO or the OECD could not affect the powers and autonomy of the cantons. One example that has been shown is the liberalization of market access for agricultural goods, where rural cantons naturally have strong interests in protecting the local agricultural sector from foreign market competition. Another example is the liberalization of trade in services, where existing monopolies and prerogatives in areas such as health, education, and public utilities lead to important challenges for the existing structures and traditions of the cantons. This is also true in the area of public procurement, where changes introduced at the global level (in the Government Procurement Agreement of the WTO) and at the European level have totally altered the procurement practices of the cantons in the last twenty years. Finally, the increasing demand to allow migration as a part of trade negotiations (supply of services through seasonal workers, access to the labour market, etc.) leads to additional concerns that influence the traditional fields of cantonal politics.

Amendments to the constitution and the adoption of the Federal Law on the Participation of the Swiss Cantons in the Foreign Policy of the Federal State in 1999 tried to accommodate the increased need to involve the cantons in foreign policy and the conclusion of international 
treaties. The cantons have also discovered the use of cantonal initiatives to influence the federal parliament in areas where they fear that the federal government is not sufficiently taking their problems into account.

The cantons have had to adapt their institutions in order to use these instruments. At the internal level, many of them have increased the resources dedicated to foreign affairs, in particular European integration). At least the bigger cantons now normally have specialized agencies in the administration that not only promote the canton to foreign investors but also follow developments in foreign policy, in particular economic aspects that might be of relevance to the canton and its direct interaction with other cantons and the federal government and parliament. Together the cantons have created bodies (in particular the $\mathrm{KdK}$ ) and arrived at a common position towards the federal government - or simply coordinated their policies and views. The fact that the federal government even accepts permanent representatives of this body in its own ministries and missions abroad (in addition to the ad hoc nomination of members of international delegations) is remarkable. At the same time, one should not overestimate the potential of the cantons in the area of foreign policy and, particularly, trade. Even the bigger cantons that can employ trade specialists may face the problem that it is not easy to convince local politicians and members of cantonal parliaments and governments with regard to the sometimes rather dry questions of international trade. Expertise in the area of trade is not evenly spread among all the Swiss cantons and their representatives at both cantonal and federal levels.

In addition, important differences between the cantons can make it difficult to come up with common positions. In recent years the divide between urbanized regions and rural areas has seemed apparent, albeit mitigated by the continuous urbanization of most of the country. Here, as in other areas of Swiss federalism, it has been voiced that the urban centres should have their own role to play in the political system, but concrete measures have not been taken so far. In these cases, the bigger (and richer) cantons may find it easier to defend their own positions directly at the federal level, something that is difficult for the smaller cantons to do.

Overall, it can be said that increased sub-federal involvement has resulted in better acceptance of the negotiation results by the cantons and therefore by the population in general, but at the price of slower and more complicated communication procedures that affect the flexibility of the federal government. The cantons have already asked for increased participation and even threatened to sue the government if a total reform of the federal system is not achieved soon (not only with 
regard to trade or foreign affairs in general). The increased use of cantonal initiatives, as well as the more common idea of using cantonal referendums against federal government decisions, in the area of trade and foreign affairs underlines this trend.

\section{NOTES}

1 Most famously, such an agreement between Uri, Schwyz, and Unterwalden of early August 1291 - the Rütlischwur, one of many military alliances, i.e., Bundesbriefe (in German) or Pactes fédéraux (in French) is traditionally used as a historic origin for the country and justifies the celebration of a national holiday on 1 August. The decision to refer to this particular document as a historic starting point is, however, rather controversial and mostly the result of the nation-building process in the second part of the nineteenth century.

2 The Federal Constitution of 18 April 1999 was entered into force on 1 January 2000.

3 For a historic case study in English see Behr (2014).

4 For an interesting study of why tensions between the language regions are less of a problem in Switzerland than in Belgium, see Wouters, Van Kerckhoven, and Vidal (2016).

5 For an account under the old constitution and before the entry into force of the Federal Law on the Participation of the Cantons in the Foreign Policy of the Swiss Confederation of 1999, see Schmitt (1994).

6 Section 1, articles 54-6, of the constitution of 1999; security, national defence, and civil defence are treated in section 2 of the same chapter (articles 57-61).

7 Articles 184 and 186 of the constitution of 1999.

8 Those relating to trade (including trade in services and public procurement) and trade-related migration are addressed in this chapter, and for other areas the following studies may be interesting: health, Trein (2017); education, Behrens (2016).

9 Bundesgesetzüber die Mitwirkung der Kantone an der Aussenpolitik des Bundes (BGMK) of 22 December 1999, AS 2000 1477, https: / / www.admin.ch.

10 See for an example a recent interview given by the president of the Conference of Cantons (Konferenz der Kantonsregierungen, KdK) in which he complains about the erosion of cantonal powers and political autonomy due (inter alia) to international agreements, in Cina (2016).

11 Article 160, paragraph 1, of the constitution.

12 For a description of the role of the federal parliament in the federal system see Granat (2017). 
13 See the official record, https:/ / www.parlament.ch/de/ratsbetrieb/ suche-curia-vista/geschaeft?AffairId=20120313.

14 Article 89, paragraph 4, of the Swiss constitution of 1974, introduced by referendum (Popular Initiative) in 1921.

15 See the detailed description of the historic development by the government in the official journal (Botschaft des Bundesrates an die Bundesversammlung über die Neuordnung des Staatsvertragsreferendums vom 23. November 1974, BBl 1974 II 1133-6).

16 In a recent debate about the ratification of an agreement between Switzerland and Germany and regarding the use of German airspace in connection with flights from and to Zurich airport, the employment of this instrument was discussed but rejected by the responsible parliamentary committee of the canton of Zurich. See the coverage in Neue Zürcher Zeitung, 29 August 2013, https: / / www.nzz.ch.

17 As a consequence, Switzerland did not join the European Economic Area, and the other EFTA members all became parties to the EEA. Today Norway, Iceland, and Liechtenstein are the remaining EFTA members in the EEA, and the others have since joined the European Union.

18 For a discussion of this proposal by the Conference of Cantons (KdK) see http://www.kdk.ch/de/themen/allgemeine-aussenpolitik/ staatsvertragsreferendum/.

19 For an official summary of the negotiations see the government statement of 10 September 2003 at https: / / www.parlament.ch.

20 See the interview with the responsible member of the government of the canton of Zurich, Ernst Stocker, in Tagesanzeiger, 6 July 2012, http:/ / www. tagesanzeiger.ch; and the official press release of the canton, https://vd.zh. ch. Some parties were not so happy and suggested that the canton reject the proposed text and even launch a procedure to request a referendum at the national level.

21 The text of the Convention on the Conference of Cantonal Governments is available in English at http:/ / www.kdk.ch.

22 The list of working groups is available online at http:/ / www.kdk.ch.

23 See the respective statement on the home page of the KdK: http:/ /www. kdk.ch.

24 For detailed information on this body see its home page, http:/ / www. bpuk.ch. The current statute dates from 20 September 2012 and has replaced the original of 18 September 2009. It is available online on the site of the organization.

25 For details on this body, a foundation under Swiss private law, with its seat in Solothurn see http:/ / www.chstiftung.ch.

26 For details see http://www.kdk.ch/de/die-kdk/sekretariat/. 
27 See, for the canton of Zurich, https: / / aussenbeziehungen.zh.ch; and for the canton of St Gallen, http:/ / www.aussenbeziehungen.sg.ch.

28 See the press release "Volkswirtschaftsdirektion vernetzt chinesische Unternehmer im Kanton Zürich," at https:/ /aussenbeziehungen.zh.ch.

29 See KdK press release of 13 January 2017, "Les Cantons disent OUI à la réforme de l'imposition des entreprises" (The Cantons say "yes" to the corporate tax reform), https:/ / kdk.ch.

30 The Ständerat (Council of States) is the second chamber, representing the twenty-six cantons (similar to the US Senate). It comprises forty-six elected Ständeräte (councillors): two represent each of the twenty "full" cantons, and one represents each of the six so-called half cantons.

31 See the two press releases at https://kdk.ch/de/aktuell/ medienmitteilungen/.

\section{REFERENCES}

BauernZeitung. 2016. Waadt fordert Ausschluss von Palmöl Freihandel. 21 April. https://www.bauernzeitung.ch.

Behr, Andreas. 2014. "The Representation of the Swiss Cantons at the Spanish Court at the End of the Seventeenth Century: A First Approach." Dimensioni e problemi della ricerca storica 27 (1): 165-92.

Behrens, Matthis. 2016. "Switzerland: Between the Federal Structure and Global Challenges." In Education in Non-EU Countries in Western and Southern Europe, edited by T. Sprague, 75-98. London: Bloomsbury Publishing.

Casado-Asensio, Juan, and Reinhard Steurer. 2016. "Mitigating Climate Change in a Federal Country Committed to the Kyoto Protocol: How Swiss Federalism Further Complicated an Already Complex Challenge." Policy Sciences 49 (3): 257-79.

Cina, Jean-Michel. 2016. Wir prüfe eine Klage gegen den Bund. Neue Zürcher Zeitung, 3 December. https://www.nzz.ch.

Federal Constitution of the Swiss Confederation of 12 September 1848. 1848. http://www.verfassungen.de.

Federal Constitution of the Swiss Confederation of 29 May 1874. 1874. http:// www.verfassungen.de.

Federal Constitution of the Swiss Confederation of 18 April 1999. 1999. https://www.admin.ch.

Füglister, Katharina, and Fabio Wasserfallen. 2014. "Swiss Federalism in a Changing Environment." Comparative European Politics 12 (4-5): 404-21.

Granat, Katarzyna. 2017. “National Parliaments as Political Safeguards of Federalism: Interparliamentary Cooperation in the EU, the US, and Switzerland." In National Parliaments after the Lison Treaty and the Euro 
Crisis: Resilience or Resignation?, edited by D. Jančič, 263-80. Oxford: Oxford University Press.

KdK (Konferenz def Kantonsregierungen). 2017. Les cantons disent OUI à la réforme de l'imposition des entreprises. 13 January. https://kdk.ch/fr/

Koordination Aussenbeziehungen. 2017. Volkswirtschaftsdirektion vernetzt chinesische Unternehmer im Kanton Zürich. 12 May. https:// aussenbeziehungen.zh.ch.

Kreis, Georg. 2012. Aussenpolitik. Historisches Lexikon der Schweiz. http:// www.hls-dhs-dss.ch.

Neue Zürcher Zeitung. 2016. Kommission lehnt Kantonsreferendum ab. 29 August. https://www.nzz.ch.

Schmitt, Nicolas. 1994. "The Foreign Policy of Spanish Autonomous Communities Compared to That of Swiss Cantons." In Evaluating Federal Systems, edited by B. de Villiers, 362-93. Dordrecht, Netherlands: Martinus Njihoff.

Schweizer, Rainer J. 1992. “Die Schweizer Kantone vor der Europäischen Herausforderung." Jahrbuch des öffentlichen Rechts der Gegenwart 40: 59.

Trein, Philipp. 2017. "Europeanisation beyond the European Union: Tobacco Advertisement Restrictions in Swiss Cantons." Journal of Public Policy 37 (2): 113-42.

Vatter, Adrian. 2016. Das Politische System der Schweiz. 2nd ed. Baden-Baden, Germany: Nomos.

Wasescha, Luzius. 1996. "Die Auswirkungen der Uruguay-Runde (GATT/WTO) auf Kantone und Länder." In GATT 94 und die Welthandelsorganisation: Herausforderung für die Schweiz und Europa, edited by S. Kux and D. Thürer, 117-27. Zurich: Schulthess.

Wouters, Jan, Sven Van Kerckhoven, and Maarten Vidal. 2016. “The Dynamics of Federalism: Belgium and Switzerland Compared." In Weak States, Strong Societies: Power and Authority in the New World Order, edited by A. Saikal, 38-58. London: I.B. Tauris. 